NBER WORKING PAPER SERIES

ASPECTS OF THE CURRENT ACCOUNT

BEHAVIOR OF OECD ECONOMIES

Jeffrey Sachs

Working Paper No. 859

NATIONAL BUREAU OF ECONOMIC RESEARCH

1050 Massachusetts Avenue

Cambridge MA 02138

February 1982

This paper was presented at the Fifth Intemational Conference of the University of Paris-Dauphine on Money and International Monetary Problems, June 15-17, 1981. I wish to thank Barry Eichengreen for helpful discussions, and Joy Mundy for assistance in preparation of the paper. The research reported here is part of the NBER's research program in Intemational Studies. Any opinions expressed are those of the author and not those of the National Bureau of Economic Research. 


\title{
Aspects of the Current Account Behavior of OECD Economies
}

\begin{abstract}
$\underline{\text { ABSTRACT }}$
This essay examines some aspects of capital flows within the OECD, and outlines a framework for analyzing current account movements. In both the theoretical and empirical sections, I argue for the importance of including investment and growth in analyses of the current account. I present empirical evidence confirming that shifts in investment rates explain a large part of recent OECD current account behavior. In addition, the links in theory and practice between exchange rates and the current account are scrutinized. A link between current account deficits and depreciation is evident for the large OECD economies, but not for many smaller European economies. It appears that the exchange rate behavior in the smaller economies can be explained by specific exchange rate policies in these economies.
\end{abstract}

\author{
Jeffrey Sachs \\ Department of Economics \\ Harvard University \\ Cambridge, MA 02138
}

(617) 495-4112 


\section{Introduction}

Many aspects of international capital mobility among developed economles are not well understood. There are puzzles about the size and distribution of current account imbalances and their counterpart, international capital flows, within the OECD. There are competing theories about the links of exchange rate movements to the current account that have not yet been sorted out empirically. Most fundamentally, there is doubt about the basic degree of capital mobility, with some (1ike Feldstein and Harioka [1981]), arguing that national capital markets are highly segmented, and others (1ike Harberger [1980]) arguing that high international capital mobility effectively equalizes rates of return in disparate financial centers. Harberger [1980] recently bemoaned this professional "schizophrenia" (p.331) in thinking about capital flows, indicating that it points to "a genuine ignorance on our collective part of how the world capital market works." 1 /

This essay examines some aspects of capital flows within the OECD, and outlines a framework for analyzing current account movements. In both the theoretical and empirical sections, I argue for the importance of including investment and growth in analyses of the current account, in contrast to much recent work which emphasizes savings (but not investment) decisions in current account determination. I present empirical evidence confirming that shifts in investment rate explain a large part of recent OECD current account behavior.

In addition, the links in theory and practice between exchange rates and the current account are scrutinized. There has been amazingly little evidence brought to bear on the basic assertion that exchange rate depreciation is correlated with current account deficits, and appreciation with surpluses. 
The assertion is made, but not tested, in Kour 1 and Macedo [1980], for example. The hypothesized link holds up well for the larger OECD economies and not for a number of smaller European economies characterized by large deficits and exchange rate appreciation in the 1970 s. But on closer scrutiny, the exchange rate behavior in the smaller countries can be explained by their specific exchange rate policies. For these countries, a link is found between deficits and rising nominal interest rates rather than depreciating currencies. 


\section{An Overview of Current Account Behavior: 1960-1979}

The broad outlines of current account behavior for fourteen OECD countries may be gleaned from Table 1. From the final line of the Table, we see the well known fact that the OECD as a whole went into deficit upon the 1973 oil price hike, after a decade-and-one-half of aggregate surpluses. Even at the point of deepest deficits, though, the ratio of the current account to gross national product, CA/GNP, for the fourteen countries in the aggregate never fell below -.005 during 1974 to 1979. Note that the smaller countries have consistently run deficits since 1960, and that CA/GNP worsened after 1973 considerably more for this group than for the larger countries, a fact which we will take up soon.

The position of a country as a capital importer (i.e., with a current account deficit) or exporter is remarkably steady over time, and is also tied closely with economic size. The largest economies (by total GNP), Germany, Japan, and the United States, have been fairly consistent capital exporters, at least until the large U.S. deficits of 1977 and 1.978. With the exception of Sweden, the small countries have all been capital importers for twenty years, with remarkable consistency. For the six small countries excluding Sweden, during 1961-79, there are only 10 observations of surplus of a total of 114 annual observations. The proportion of surplus years between 1960 and 1979 is shown in the last column of Table 1 . Of the large countries, only Canada is consistently in deficit; of the small, none is typically in surplus.

An indicator of the persistence of surpluses and deficits across years is given by the correlation of CA/GNe for the list of countries across subperiods. Between 1960-65 and 1966-73, the correlation for thirteen countries (excluding France) is .81. For the periods 1966-73 and 1974-79, 
the correlation is $\mathbf{r}=0.72$.

Also, the absolute magnitude and variability of CA/GNP is negatively related to economic size. For the group of large countries as a whole, the 1960-79 range of CA/GNP is 0.004 to -0.004 , while for the small countries, the range is 0.003 to -0.044 . The standard deviation of $\mathrm{CA} / \mathrm{GNP}$ for the large eight economies is 0.003 , much less than 0.011 for the smaller countries. This same point was made by Harberger [1980], using the ratio of CA to gross investment 1 rather than to GNP. The result probably reflects the fact that small countries are truly "small" in international capital markets, and can borrow and lend internationally at a fairly fixed interest rate, while larger economies face an upward sloping schedule of international funds. We return to this point later in the paper.

Note that the deficits are a substantial fraction of gross domestic investment in many of the countries. For the smaller countries as a group, international capital inflows accounted for more than eleven per cent of the funds for gross domestic investment during 1974-79. This ratio is an astonishing 22.6 per cent for Norway; Norway's deficits, we shall note later, reflect international borrowing to finance Norway's North Sea oil development .

My regression analysis to date has focused more on the sources of shifts in the current account, than on the reasons for persistent imbalances, though the theoretical discussion below clearly points to factors which can explain long periods of international borrowing. Current account flows over decades can be expected between countries with similar tastes but unequal marginal productivities of capital, either because of different technologies, a different industrial $\mathrm{mix}$, or different initial endownents of capital. Alternatively, CA imbalances can occur between countries with similar technologies, but differing intertemporal consumption preferences (1.e. 
savings behavior). If differing technologies or capital endowments are the main source of capital flows, we would expect to see persistent deficits in economies with high investment rates. This is indeed the case for the large versus small OECD economies. The I/GNP ratio for the smaller six countries is consistently three to four percentage points above the same ratio among the large eight economies. For our three subperiods, these rates are given by:

\begin{tabular}{lcccc} 
& & & & \\
& & $1960-65$ & $1966-73$ & $1974-79$ \\
\hline$(I / G N P)$, large 8 & $.21^{a}$ & .22 & .22 \\
$(I / G N P), \operatorname{smal1} 6$ & .26 & .26 & .25 \\
& ${ }^{a} 1961-65$ & Source: & International Financial Statistics
\end{tabular}

On a country-by-country. basis, Japan is the significant exception to the negative link of $\mathrm{CA} / \mathrm{GNP}$ and I/GNP. The Japanese CA/GNP ratio is usually positive although the investment share I/GNP is the highest among the fifteen countries studied. My guess is that Japanese capital controls until the late 1970 s explain the low CA/GNP ratio. 2 In the absence of controls, Japan's extraordinary savings rates would likely have led to large CA surpluses, and smaller investment rates. Since the capital controls effectively bottled up the savings domestically, in spite of Japanese home interest rates much below international levels, CA/GNP was reduced and I IGNP was raisea.

As a further check on the investment relation, I ran a cross-section of CA/GNP and I/GNP for a number of subperiods, with and without Japan included. These are shown as regressions 1 to 3 in Table 2. The correlation between investment rates and CA/GNP is particularly strong after 1970. 
If differing endowments of capital, rather than differences in technologies or product mix are behind the persistent differences in investment rates, the International flow of capitat would be from high per capita Income countries to lower per capita income countries. Surprisingly, the simple relationship between CA/GNP and real per capita income is negative, not positive, and extremely weak, as shown in regression 4. Other writers have found a weak or negative relationship between per capita income and the current account balance in examining flows between developed and developing countries. $3 /$ Apparently low per capita incomes are as much evidence of low total factor productivity as of low endowments of ćapital per head.

- It is often thought that the recent pattern of current account deficits and surpluses reflects in part the distribution of oil import dependence among nations. I have argued at length in Sachs [1981] that the links between oil dependence and deficits were rather weak in the 1970s, for good theoretical reasons. As an illustration of this proposition, regression 5 and 6 show CA/GNP as a function of I/GNP and $\mathrm{M}^{\text {oil }} / \mathrm{GNP}$, where $\mathrm{M}^{\mathrm{O} 11}$ is the value of net petroleum imports into the country. All variables are averaged over 1970-79. There is no overall negative relationship between oil dependence and CA/GNP and the oil variable is weak and statistically insignificant. The basic explanation here is that while countries with higher oil dependence, cet. par., suffered greater real Income losses after the oil price increases in the 1970s, real income losses per se do not lead to international borrowing. In principle, it is crucial whether the income losses are perceived as permanent or temporary; only in the latter case will deficits be greatest in countries with the largest income losses. A second part of the explanation 
Is that oil-rich countries, such as Canada, Norway and the U.K., experienced a sharp rise in investment expenditures on energy resource development, and these expenditures contributed to current account deficits.

The links betweer investment and the current account are even stronger when we consider shifts in international borrowing. With great consistency, the countries that had the largest increase in CA deficits in the 1970 s were those with the sharpest rise in gross investment. As seen in regression $7,\left[(\mathrm{I} / \mathrm{GNP})_{71-79}-(\mathrm{I} / \mathrm{GNP})_{61-70}\right.$ ] accounts for 66 per cent of the variance in $\left[(\mathrm{CA} / \mathrm{GNP})_{71-79}-(\mathrm{CA} / \mathrm{GNP}) 61-70\right]$. Since the coefficient on investment is -0.65 , a one per cent $r$ ise in the investment raté was financed on average 0.65 per cent by foreign capital inflows, and only 0.35 per cent by gross national savings.

In principle, exogenous: increases in domestic savings rates, in addition to shifts in investment, might explain the recent current account behavior. Indeed the theoretical section stresses that a great variety of shocks can potentially account for CA movements. Our empirical task is to sort out which of the possible shocks is the likely candidate for having moved the current account in any particular period, and here the evidence strongly points to investment shifts as opposed to savings shifts as the major influence. As seen in regression 8 in Table 2, shifts in national savings rates are virtually uncorrelated with $C A$ shifts between the decades of the 1960 s and 1970 s. The $R^{2}$ is only 0.01 , and $\Delta(S / G N P)$ is statistically insignificant.

On a country-by-country time series basis, we again find a large role for shifts in investment rates in $\mathrm{CA}$ swings and an apparently smaller role for shifts in savings rates. The simple correlation (not shown) during 1961-1979 between (detrended) CA/GNP and (detrended) I/GNP is negative in thirteen of the 
fourteen countries, with $r<-.50$ in six cases. The (detrended) savings rates, as expected, are positively correlated to (detrended) CA/GNP, for twelve of the fourteen countries, though the correlation is generally weaker; $r>.50$ in three countries.

$\uparrow$ 
An Overview of Exchange Rate-Current Account Linkages: 1973-80

With the great extent of theorizing about current account effects on the exchange rate, there has been remarkably little attempt to verify competing hypotheses. Before we explore what theory says the links - should be, let's examine what the links have been. While there are many potential hypotheses to test, I will focus on the view that deficit countries will have depreciating nominal and real exchange rates, and surplus countries the opposite. With respect to the current account Influences on the nominal exchange rate, Kouri has dubbed this view the "accelerationist" hypothesis.

Proponents of this view, of course, recognize that domestic financial policies can upset any simple link between deficits and depreciation, but argue that the hypothesis is supported empirically, in spite of potential complications. As Kouri and Macedo [1981] write:

Allowing for the effects of intervention, changes in interest rates and so on there is still a clear tendency of currencies of surplus countries to appreciate continuously and those of deficit countries to depreciate continuously.

... [referring to evidence on the large 7 countries] cumulative autonomous capital flows have been insufficient to finance the substantial imbalances that have existed since 1973. Year after year, furthermore, they have often accentuated the pressure on the exchange rate of deficit countries....

Table 3 offers the basic data to test this proposition. The exchange rate for each country is a geometric weighted average of the country's bilateral exchange rates with the other countries, where the weights are country shares in total international trade during 1968-73. The real exchange rate $E P^{*} / \mathrm{P}$ is similarly calculated, using the wholsale price 
index as the price variable. Among the large countries, there is a clear pattern of nominal and real exchange rate appreciation among surplus countries (Germany, Japan, the Netherlands) and depreciation among the rest (Canada, France, Italy, U.K., and U.S.). The correlations of both nominal and real exchange rate changes with (CA/GNP) are negative for all of the large countries except Canada. Regression equations of $\% \Delta(E)$ on lagged $\% \Delta(E)$ and $(\mathrm{CA} / \mathrm{GNP})$, shown in Table 4, tell a similar story. Interestingly, the pattern seems to break down for many of the smaller countries, where we observe large deficits together with nominal and real exchange rate appreciations. Norway, for example, had deficits of over 10 per cent of GNP in 1976, accompanied by real and nominal exchange rate appreciation of over 6 per cent throughout the year. Austria, similarly, experienced real appreciation in the midst of seven consecutive years of deficit. Nor is there a negative correlation between exchange rate movements and the current account on an annual or quarterly basis. In almost all cases the correlations are positive or weakly negative, and the regression coefficients are statistically insignificant.

Table 5 packages the data in a slightly different format, by simply counting for each country the number of observations in which surpluses and deficits are associated with nominal and real appreciations and depreciations. An $\chi^{2}$ statistic is used to test for independence of the current account position and the direction of exchange rate movement. Again, there is a clear pattern of nominal and real depreciation cum deficits in the large countries, versus nominal and real appreciation cum deficits in many of the smaller countries. There are as many observations of deficits with appreciation as with depreciation for the smaller countries.

What explains this difference in behavior? Clearly, a major step 
towards explanation is a difference in exchange regimes in the small and large countries. Of the large countries, the U.S., U.K., Canada and Japan have been floating throughout the-entire period 1973-80, and France and Italy floated for most of the period $4 /$ Germany has been at the center of a series of cooperative exchange arrangements, first the "Snake" and since March 30, 1979, the European Monetary System (EMS). The Dutch guilder has remained fairly closely linked to the Deutschemark, first in the Snake and now in the EMS.

The smaller countries, with the exception of Australia, have all maintained some linkage to a group of currencies, either formally as members of the Snake and EMS (Belgium, Denmark, Norway for a period), or informally by pegging to a basket of currencies (Austria, Finland, Norway, Sweden) $5 /$ Since the theory of nominal. exchange rate movements and the current account is predicated on a floating regime, it is perhaps not surprising that the smaller countries fail to support the "accelerationist" view. With respect to real exchange rates, the difference in exchange regime provides little answer to the differences in behavior of large and small countries. Most of the links between CA/GNP and P/EP* that have been described in the literature apply to both fixed and flexible rate regimes, as we shall see.

There is still a quandry, though, with the smaller countries. If we maintain the assumption of the imperfect substitutability of home and foreign assets which underlies the accelerationist view, we know that a deficit country can peg its exchange rate only at the expense of continued official reserve outflows, or increasingly contractionary monetary policies with rising domestic interest rates. There is no evidence of significant use of official reserves to finance the post-73 deficits, and indeed for 
these countries official reserves increased in almost all of the years between 1973 and 1979. With respect to interest rates, we can check the Imperfect capital mobility assumption by examining whether interest rate differentials with Deutschemark assets tended to increase during deficit years for the currencies pegged to the DM (Austria, Denmark, the Netherlands, and Norway until December 12, 1978). As seen in Table 6, there is a clear pattern of rising differentials during the deficit years for all of the countries. Correlations of annual changes in interest rate differentials with $\mathrm{CA} / \mathrm{Y}$ show a negative link for each of the countries except Denmark (see Table 6 ).

With this brief overview, we turn to the theoretical section. The goal is to embed international capital flows in a model that can explain: (1) the persistence of current account deficits and surpluses, (2) the large role of investment shifts in current account movements: (3) the co-occurrence of deficits and exchange depreciation in floating exchange rate economies, and (4) the ambiguous links between the real exchange rate and the current account. 


\section{A Theoretical Model of the Current Account}

In a series of recent papers, I have developed an infinite-horizon, two-country model of the current account under assumptions of economic growth with far-sighted households, value-maximizing competitive firms, and efficient asset markets. Since an analytical solution to the model is apparently beyond reach, I have examined the model with computer simulations. In this section I sketch a two-period, one country analog to the model, that preserves the basic structure and results of the more complete analysis. The strength of the approach is that it illustrates how specific exogenous shocks induce particular correlations between key variables, such as $C A$ with $P / E P$ and $I$.

Most recent models analyzing the links of the current account to the exchange rate and to other variables, have failed to properly model current account behavior. Typically, the current account balance is written as a simple function of the exchange rate and current financial wealth (as in Kouri [1981], Dornbusch and Fischer [1980], and Rodriguez [1981]). There is almost never any treatment of physical capital accumulation, and its relationship to wealth holdings. Moreover, the current account equation gives inadequate results for many types of questions, since the savings behavior that is implied by the equations is not credible. Thus, in Dornbusch and Fischer [1980] for example, consumption is not a function of human wealth, or the discounted value of domestic output. We will see that many disturbances affect the current account precisely by altering the discounted value of domestic output, and such channels are necessarily ignored in the Dornbusch-Fischer model. In Rodriguez [1980], all anticipated disturbances to the economy have an 
Impact on the current account only through real balance effects, probably the least important of all the relevant channels.

Failure to treat investment and capital accumulation is not an innocent simplification, if we are to draw real-world conclusions from our models of exchange rate behavior. By excluding all wealth accumulation except in the form of foreign assets, these models set up a one-to-one link between the change in wealth, and the current account balance. With domestic investment, however, real wealth may be increasing or decreasing along with CA surpluses and deficits. Again, in Dornbusch-Fischer, the exchange-rate links to the current account are mediated entirely by changes in wealth. A deficit signals declining wealth and thus declining money demand cum depreciation. With investment explicitly treated, a CA deficit may easily be matched with rising wealth and appreciation, particularly if the deficit reflects an investment boom.

It is not enough to add investment as a component of expenditure to arrive at a general theory of the current account. In addition, we must include the returns to investment as part of the wealth of firms' shareholders and allow that wealth to affect current consumption decisions. This general equilibrium structure is readily built into the simple model now presented.

We consider an economy which produces a single final output, with price P. The economy is small in the world capital market, so that domestic agents can borrow and lend in foreign denominated bonds at a fixed interest rate $r^{*}$. The domestic output is an imperfect substitute in consumption for a foreign final good that has world price $\mathrm{P}^{*}$ and domestic price EP*, where $E$ is the exchange rate. The home country is assumed to be small in its import market, so that $P *$ is exogenous, and may be considered fixed. 
All international capital flows take place in one-period foreign denominated bonds; I denote the end-of-perfod domestic net holdings of these bonds as $z_{t}$. Domestic equity is internationally tradeable, and is a perfect substitute for $z$, so that the required return on equity, in foreign currency units, is $r^{*}$. The only outside asset denominated in domestic currency is non-interest bearing money, $M$. Inside domestic bonds have interest rate 1 , which may differ from the return on foreign assets because of the portfolio preferences of domestic agents. Neither domestic money nor the domestic bond is held by foreigners.

In assuming perfect substitutability of home equity and foreign bonds (or foreign equity), but imperfect substitutability of domestic and foreign bonds, I am deviating from a typical assumption that home assets are better substitutes with each other than each is with foreign assets. Of course, there is no theoretical assumption that is "right" in this regard: relative asset substitutability depends on the nature of underlying stochastic shocks in the economy, and on the structure of trade. Kouri [1981] has pursued the hard work of linking an array of exogenous disturbances to optinal asset demand functions in a general equilibrium model. We are still far off from concrete results in this area for open-economy macroeconomic models, and I do not pursue the ambitious task of solving endogenously for the structure of portfolio choices.

Households make their consumption decisions to maximize a two-period, additively separable utility function, subject to the constraint that the discounted value of consumption must equal initial wealth 


$$
\begin{aligned}
& c_{1}^{D}, c_{1}^{F}, c_{2}^{D}, c_{2}^{F} U\left(c_{1}^{D}, c_{1}^{F}\right)+\frac{1}{1+\delta} U\left(C_{2}^{D}, c_{2}^{F}\right) \\
& \text { s.t. } \quad\left(\pi_{1} c_{1}^{D}+c_{1}^{F}\right)+\frac{1}{1+r^{*}}\left(\pi_{2} c_{2}^{D}+c_{2}^{F}\right)=w_{1}
\end{aligned}
$$

In this equation, $\pi_{t}$ is the period $t$ relative price of home goods to foreign $\operatorname{goods}\left(\pi=P_{t} / E P^{*}\right)$, and $W_{1}$ is the initial wealth, in units of the foreign final good. $C_{t}^{D}$ is consumption of the home good, and $C_{t}^{F}$ is consumption of the foreign good. By additive separability, the household first determines total spending each period $\pi_{t} C_{t}^{D}+C_{t}^{F}$, and then determines the composition of spending between $C_{t}^{D}$ and $c_{t}^{F}$.

To stay as simple as possible, I choose $U(\cdot, \cdot)$ to be $\log \left(C_{t}^{D^{\alpha}} C_{t}^{F}\right)$. Then the optfmal expenditures are given by:

$$
\begin{aligned}
& c_{1}^{D}=\frac{\alpha(1+\delta)}{(2+\delta) \pi_{1}} W_{1}, \quad C_{1}^{F}=\frac{(1-\alpha)(1+\delta)}{(2+\delta)} w_{1} \\
& c_{2}^{D}=\frac{\alpha\left(1+r^{*}\right)}{(2+\delta) \pi_{2}} W_{1}, \quad C_{2}^{F}=\frac{(1-\alpha)\left(1+r^{*}\right)}{(2+\delta)} w_{1}
\end{aligned}
$$

The discounted value of expenditure on each of the goods $c_{1}^{D}, c_{1}^{F}, c_{2}^{D}, c_{2}^{F}$ is a constant share of wealth by the assumption on utility.

Managers are assumed to maximize the market value of firms. By the assumption that the cost of capital $r *$ is set in the world equity market, firm valuation is simply the present discounted value of total earnings, net of investment expenditure $\left(I_{1}\right)$ :

$$
V=\left(\pi_{1} Q_{1}-\pi_{1} w_{1} L-I_{1}\right)+\frac{\left(\pi_{2} Q_{2}-\pi_{2} w_{2} L\right)}{1+r *}
$$

Output is produced according to the production function $Q_{t}=F\left(K_{t}, L_{t}\right)$ and $\mathrm{K}_{2}=\mathrm{K}_{1}+\mathrm{I}_{1}$. (I assume that all capital goods are imported, so that investment expenditure in terms of the foreign good $I_{1}$ also equals the quantity of new capital,) We will assume continuous full employment 
$\mathrm{L}_{1}=\overline{\mathrm{L}}$. Obviously, first-order conditions for value maximization are given by:

$$
\frac{\partial Q_{t}}{\partial L_{t}}=W_{t} ; \quad: \pi_{2} \frac{\partial Q_{2}}{\partial K_{2}}=\left(1+r^{*}\right)
$$

In the spirit of simplicity, I will assume that the production function is Cobb-Douglas, with $Q_{t}=\bar{L}^{-\beta} \mathrm{K}_{t}^{1-\beta}$.

Domestic wealth is given by the sum of human wealth (H), domestic ownership of equities, and net foreign investment. I will assume that households own the entire domestic capital stock, and that all international capital flows are chages in $Z$. There are no initial holdings of $Z$. In this model, the issue of portfolio composition between equity and $Z$ is unimportant since equities and $Z$ earn the same rate of return. All that matters is that at the beginning of the first period, domestic households own the claims to domestic firms. Human wealth is the present value of total labor earnings $\pi_{1} \mathrm{w}_{1} \mathrm{~L}_{1}+\left(\pi_{2} \mathrm{w}_{2} \mathrm{~L}_{2}\right) /\left(1+\mathrm{r}^{*}\right)$. Adding up the components of wealth, we have:

$$
W=\pi_{1} Q_{1}+\frac{\pi_{2} Q_{2}}{1+r^{*}}-I_{1}
$$

Domestic money demand is set, without formal justification, according to a transaction demand specification

$$
\frac{M_{t}}{P_{t}}=Q_{t}^{\phi}(1+i)_{t}^{-\theta}
$$

Here, real balances are an increasing function of domestic output and a declining function of the domestic interest rate 1 . Because this is a two-period model, second period money demand is inherently problematic as there are presumably no alternative assets to money in the last period 
(and thus no second-period interest rate 1) and no explicit reason to hold money. I will arbitrarily $f\left(x 1_{2}\right.$ to the exogenous world interest rate $1^{*}$ (any constant would do); a better solution only emerges in an infinite horizon model, or in a finite-horizon model with a very explicit transactions technology.

The domestic interest rate is determined according to portfolio preferences for home versus foreign assets. As I've noted, in more sophisticated models the portfolio problem is solved with explicit attention to the types of shocks in the economic environment. Here I fall back to a reduced form specification, as in a model of Kouri [1981], in which the nominal interest rate differential between the home and foreign asset, net of expected exchange rate changes, is a declining function of the stock of foreign assets held domestically:

$$
\left[1+i_{t}\right] /\left[\frac{E_{t+1}}{E_{t}}\left(1+i^{*}\right)\right]=f\left(z_{t}\right) \quad f^{\prime}\left(z_{t}\right)<0, f(0)-1, f>0 .
$$

In our two period case, $z_{1}=\mathrm{CA}_{1}$. In a multiperiod model, $z_{t}=\sum_{i=1}^{t} \mathrm{CA}_{i}$. The model is completed by adding an export demand equation and market clearing conditions:

$$
X_{t}=\frac{Y *}{\pi_{t}}
$$

and

$$
Q_{t}=c_{t}^{D}+x_{t}
$$

$X^{*}$ is a world export demand shift varable, presumably reflecting foreign income or wealth.

Our goal is to solve for $\mathrm{CA}_{1}$, the first period current account, and to relate $\mathrm{CA}_{1}$ to the parameters of the model, and to $\mathrm{E}_{2} / \mathrm{E}_{1}$ and $\pi_{2} / \pi_{1}$, the rates of nominal and real exchange rate change. The first-period current account 
at world prices, is simply given by,

$$
C A_{1}=\pi_{1}\left(Q_{1}-C_{1}^{D}\right)-C_{1}^{F}-I_{1}
$$

and $\mathrm{CA}_{2}=-\mathrm{CA}_{1}$ by the household budget constraint. From (2), we have consumption as a function of $W$, and in (5), we have the definition of $W$. Thus, substituting in (10), we can write $\mathrm{CA}_{1}$ as

$$
C A_{1}=\frac{\pi_{1} Q_{1}\left(r^{*}-\delta\right)}{(2+\delta)\left(1+r^{*}\right)}-\frac{\left(\pi_{2} Q_{2}-\pi_{1} Q_{1}\right)(1+\delta)}{(2+\delta)\left(1+r^{*}\right)}-\frac{I_{1}}{2+\delta}
$$

Of course this expression is not yet in final form, since $\pi_{1}, \pi_{2}, Q_{2}$ and $I_{1}$ are endogenous, and indeed $Q_{2}$ is a function of $I_{1}$. Still, (11) points up the three fundamental determinants of current account balance. The first term on the $\mathrm{right}$ hand side shows that $\mathrm{CA}_{1}$ is an increasing function of the difference between the world interest rate and the rate of time preference $\left(I^{*}-\delta\right)$. This difference determines the desire to save income for later consumption. In the continuous time version of the present model, $\dot{W}=\left(r^{*}-\delta\right) W$, so that $r^{*}-\delta$ in fact determines the path of overall wealth accumulation.

The second term might be described as capturing the role of transitory fluctuations in current account determination. When export demand falls temporarily in a given year, pulling down real income, households dissave not because they are poor but because their transitory income is less than permanent income. In the attempt to smooth the income stream, households borrow in early periods if the real income stream is rising, and lend initially if the real income stream is falling. Thus, $C A_{1}$ decreases with $\left(\pi_{2} Q_{2}-\pi_{1} Q_{1}\right)$.

The third term highlights the special role of investment in current account determination. Since $C A_{1}=\pi_{1} Q_{1}-\left(C_{1}^{F}+\pi_{1} C_{1}^{D}+I_{1}\right)$, the effects on $\mathrm{CA}_{1}$ of an exogenous shock that causes $I_{1}$ to $r$ ise depend on the effects of the shock on $C_{1}^{F}+\pi_{1} c_{1}^{D}$. To the extent that the shock has no effect on 
hou sehold wealth, consumption will not change; $\left(\pi_{1} C_{1}^{D}+C_{1}^{F}+I_{1}\right)$ and thus the deficit $\left(=i_{1}+\pi_{1} c_{1}^{D}+c_{1}^{F}-\pi_{1}^{2}\right)$ will rise one-for-one with the investment boom. This is precisely the case for a $r$ ise in investment projects that just earn the market rate of return, $r^{*}$. If domestically owned firms retain earnings to invest in projects with return $r^{*}$, households dissave by the same amount, keeping $C_{1}$ constant. Though the first-period dividend flow to households is reduced by the $r$ ise in $I_{1}$, households "pierce the corporate veil," and dissave. They effectively substitute the firms' investment for their household savings, so that total absorption is Increased one-for-one with $I_{1}$.

Sometimes a rise in $I_{1}$ also signals "good news" that raises household wealth. For instance an anticipated rise in future world demand for domestic output raises both $I_{1}$ and $w$. In this case, both $\pi_{1} c_{1}^{D}+c_{1}^{F}$ and $I_{1}$ rise, and the deficit worsens more than one-for-one with the increase in $I_{1}$.

To solve for the reduced form for $C A_{1}$, and $\pi_{1}$ and $\pi_{2}$, we must $f$ irst determine wealth $\mathrm{W}$ in terms of the underlying parameters: $\mathrm{Y}_{1}^{*}, \mathrm{Y}_{2}^{*}, \mathrm{r}^{*}, \mathrm{~K}_{1}$, $\delta$. A couple of facts are helpful here. First, by the assumption of Cobb-Douglas technology, $\left(1+r^{*}\right) K_{2}=(1-\beta) \pi_{2} Q_{2}$, so that investment $I_{1}\left(=K_{2}-K_{1}\right)$ is given by

$$
I_{1}=\frac{(1-\beta) \pi_{2} Q_{2}}{1+r^{*}}-K_{1}
$$

Second, $\pi_{1} Q_{1}$ and $\pi_{2} Q_{2}$ are linear in $W, Y_{1}^{*}$, and $Y_{2}^{*}$. When the consumption and investment equations are plugged into (5) and (9), we find Wond $C A_{1}$ :

$$
\begin{aligned}
& W=\Delta^{-1}(2+\delta)\left(Y_{1}^{*}+\frac{\beta Y_{2}^{*}}{1+r^{*}}+K_{1}\right) \\
& \Delta=(2+\delta)-\alpha(1+\delta)-\alpha \beta>0
\end{aligned}
$$




$$
\mathrm{CA}_{1}=\Delta^{-1}\left\{[1-\alpha] \mathrm{Y}_{1}^{*}-[(2+\delta)-\alpha(1+\delta)-\beta] /\left[1+\mathrm{r}^{*}\right] \mathrm{Y}_{2}^{*}+[1-\alpha] \mathrm{K}_{1}\right\}
$$

We will interpret this expression shortly. To find the terms of trade $\pi_{1}$, note that $\pi_{1} Q_{1}=\left[\alpha(1+\delta) /(2+\delta) W+Y_{1}^{*}\right]$ from (2), (8) and (9). Thus

$$
\pi_{1}=\frac{1}{Q_{1}}\left[\frac{\alpha(1+\delta)}{2+\delta} W+Y_{1}^{*}\right]
$$

(Remember that $Q_{1}$ is fixed, since $K_{1}$ is predetermined, $L_{1}=\bar{L}$, and $\left.Q_{1}=F\left(K_{1}, L_{1}\right).\right) \quad \pi_{2}$ is found similarly, though now $Q_{2}$ is endogenous. To find $Q_{2}$, we use the investment equation (12), $K_{2}=K_{1}+I$, and $Q_{2}=L^{B} K_{2}^{1-B}$. The solution for $\pi_{2}$ is

$$
2=\left[\frac{1+r^{*}}{1-\beta}\right]^{1-\beta} \cdot\left[\frac{1}{\bar{L}}\right]^{\beta}\left[\frac{\alpha\left(1+r^{*}\right)}{2+\delta} W+Y_{2}^{*}\right]
$$

Finally, the ratio $\pi_{2} / \pi_{1}$ is given, after a bit of algebra, by:

$$
\frac{\pi_{2}}{\pi_{1}}=\frac{\alpha\left(1+r^{*}\right) Y_{1}^{*}+[(2+\delta)-\alpha(1+\delta)] Y_{2}^{*}+\alpha\left(1+r^{*}\right) K_{1}}{[(2+\delta)-\beta \alpha] Y_{1}^{*}+\left[\alpha(1+\delta) /\left(1+r^{*}\right)\right] Y_{2}^{*}+\alpha(1+\delta) K_{1}}\left[\left(1+\frac{I_{1}}{K_{1}}\right)-(1-\beta)\right]^{\prime}
$$

These bulky equations are in fact easy to interpret. To start with $\mathrm{CA}_{1}$, a rise in $\mathrm{Y}^{*}{ }_{1}$ cet. par. necessarily improves the current account, and an anticpated rise in $Y_{2}^{*}$ necessarily worsens the current account. In both cases, the rise in world demand causes an increase in wealth, and in $\pi_{1}, \pi_{2}$, and $I_{1}$. But when $Y_{1}^{*}$ rises, hou seholds save some of the first period income gain ( $1 . e$. run a surplus) to spread the consumption windfall across time; when $Y_{2}^{*}$ rises, households borrow against the anticipated future windfall to enjoy higher consumption in the initial period. Since an increase in $Y^{*}$ in either period leads to a demand increase in both periods, $\pi_{1}$ and $\pi_{2}$ both rise. Also, $I_{1}$ rises, since $\pi_{2} Q_{2}$ is increased, and $I_{1}$ is linear in second-period real income (see (12)).

An equal rise in $\mathrm{Y}_{1}^{*}$ and $\mathrm{Y}_{2}^{*}$ has an ambiguous effect on $\mathrm{CA}_{1}$. But in the benchmark case $\mathrm{r}^{*}=\delta$, a "permanent" rise in $\mathrm{Y}^{*}$ (i.e. $d Y_{1}^{*}=\mathrm{dY}_{2}^{*}$ ) leads to a deficit on $\mathrm{CA}_{1}$ ! This is sharply counter to the conventional view 
that the current account improves when demand shifts permanently towards a country. But the reason is clear enough. Higher $\mathrm{Y}^{*}$ increases investment demand, throwing $\pi_{1}\left(Q_{1}-C_{1}\right)-C_{1} F-I_{1}$ negative. In a model without investment (e.g. $B=1, K_{1}=0$ in the present case), and with $Y_{1}^{*}=Y_{2}^{*}$, $r=\delta$, a rise in $Y^{*}$ has no effect on the current account. Rather, $\pi_{1}$ and $\pi_{2}$ rise in equal proportion, and the value of exports and imports rise by the same amount.

Finally, note that $\mathrm{CA}_{1}$ is an increasing function of the initial endowment of capital. Higher $K_{1}$, cet. par., reduces $I_{1} / K_{1}$, which in turn induces an improvement in the current account. All other things equal, capital flows should lead from highly capital-endowed economies to poorly capital-endowed economies.

What can we say about the 1 inks of $\mathrm{CA}_{1}$ and real depreclation? It Is possible to find every combinations of $\mathrm{CA}_{1} \gtrless 0$ together with $\pi_{2} / \pi_{1} \gtrless 1$. What is crucial is the source of the current account imbalance. Consider two countries that are identical except for $\delta$. We can easily verify from (16) that $\frac{\partial\left(\pi_{2} / \pi_{1}\right)}{\partial \delta}<0$, and from (14) that $\frac{\partial C A_{1}}{\partial \delta}<0$. Thus, when current account differences reflect.taste differences, high deficit countries will experience real depreciation. On the other hand, for two countries that are identical except for future demand $\mathrm{Y}_{2}{ }_{2}$, the opposite conclusion is reached. Higher $Y_{2}^{*}$ unambiguously leads to higher $\pi_{2} / \pi_{1}$, and to a fall in $\mathrm{CA}_{1}$. Similarly, a temporary decline in world demand $\left(d Y_{1}^{*}<0 ; d Y_{2}^{*}=0\right.$ ) causes $\pi_{2} / \pi_{1}$ to rise and $C A_{1}$ to fall. First-period deficits are again associated with real exchange rate appreciation. If the countries differ only in $k_{1}$ the effects on the relative $\pi_{2} / \pi_{1}$ are ambiguous. In general, with $\mathrm{Y}_{1}^{*} \doteq \mathrm{Y}_{2}^{*}$ and $\delta \doteq \mathrm{r}^{*}$, faster growing countries will see a larger decline in $\pi_{2} / \pi_{1}$. Since growth in $Q_{2} / Q_{1}$ is inversely 
related to $\mathrm{K}_{\mathrm{J}}$, we should expect, cet. par., that countries with initially poor endowments of capital to experience relative large real exchange rate depreciation over time. As noted above, such countries will also, cet. par., have larger CA deficits.

At this point, we can bring in the monetary side to find the links between $\mathrm{CA}_{1}$ and nominal exchange rates. The monetary subsystem was given in (6) and (7). Noting that $P_{1}=\left(E_{1} P^{*}\right) \pi_{1}$ and $P_{2}=\left(E_{2} P^{*}\right) \pi_{2}$ and substituting into the money demand equations, we can write:

$$
\left.\frac{E_{2}}{E_{1}}=\left(\frac{M_{2}}{M_{1}}\right) \underset{\pi_{2}}{\pi}\right)\left(\frac{Q_{1}}{Q_{2}}\right) \cdot \frac{\left(1+i^{*}\right) \theta}{\left(1+i^{*}\right) \theta_{1}}
$$

From the portfolio equation (7), $\left(1+r^{*}\right) /(1+1)=\left(E_{1} / E_{2}\right) f\left(C A_{1}\right)$. Remember that $\delta$ measures the substitutability of home and foreign denominated nominal bonds, with $f=1$ for the case of perfect substitutability. Thus, plugging into (17), we have

$$
\frac{\mathrm{E}_{2}}{\mathrm{E}_{1}}=\left[\left(\frac{\mathrm{M}_{2}}{\mathrm{M}_{1}}\right)\left(\frac{\pi_{1}}{\pi_{2}}\right)\right]^{1 /(1+\theta)} \underset{\left(\frac{1}{\mathrm{Q}_{2}}\right)}{\phi /(1+\theta)}\left[\mathrm{f(CA_{1 } ) ] ^ { - 1 / ( 1 + \theta ) }}\right.
$$

For the individual periods we have:

$$
\begin{aligned}
& \mathrm{E}_{1}=\mathrm{M}_{1}^{1 /(1+\theta)} \mathrm{M}_{2}^{\theta /(1+\theta)} \mathrm{Q}_{1}^{-\phi(1+\theta)} \overline{\mathrm{Q}}_{2}^{\theta}{ }^{\theta \phi(1+\theta)} \pi_{2}^{-\theta /(1+\theta)} \pi_{1}^{-1 /(1+\theta)}[\mathrm{f}(\mathrm{CA})]^{1 /(1+\theta)} \\
& \mathrm{E}_{2}=\mathrm{M}_{2} \mathrm{Q}_{2}^{-\phi}\left(1+\mathrm{i}^{*}\right)^{\theta} \pi_{2}
\end{aligned}
$$

Not surprisingly, both real and purely monetary factors affect the exchange rates. Changes in $M_{1}$ and $M_{2}$ can move $E_{1}$ and $E_{2}$ with no effects on $\dot{C A}_{1}$, $\pi_{1}$, $\pi_{2}$, etc. under the assumptions of the model. For given $M_{1}, M_{2}$, real exchange rate appreciations and depreciations tend to cause nominal exchange rate appreciations and depreciations. Thus, as Stockman [1980] has indicated, much of the observed correlation between changes in $\mathrm{E}$ and $\mathrm{EP} * \mathrm{P}$ may be due 
to common responses to underlying shocks. This is in contrast to the more typical assumption that changes in $E$ cause $E P * / P$ to move because of nominal price rigidity.

We also see a direct effect of $\mathrm{CA}$ imbalance on the nominal exchange rate, working through the Kouri-Branson portfolio demand channel. Thus, even if a deficit economy is on a path of real appreciation, rising output, and stable money supply, it may experience nominal depreciation as its net indebtedness grows over time. Of course only in the case of perfect capital mobility, $f^{\prime}=0$, does this effect go away.

Thus, to sum up, a deficit country will surely experience nominal and real depreciation if the deficit is caused by high $\delta$. If, on the contrary, the deficits arise from a path of increasing $Y^{*}$, then $\pi_{2} / \pi_{1}$ will be large, and the nominal exchange rate will tend to appreciate unless - $f^{\prime}$ is also large. 
Extensions and Conclusions

There are at least three important directions for extending the theoretical framework described above. These are: a multiperiod or infinite-horizon analysis with more general functional forms; the introduction of capital control restrictions as a policy instrument; and an explicit treatment of portfolio considerations in a setting with uncertainty and risk averse agents.

The first is, in a sense, easy and already accomplished (cf. Sachs [1982, forthcoming], Lipton and Sachs [1980]). An infinite horizon, twocountry version of the model here has been developed and analyzed through simulation. There is no reason to stick with particular functional forms as in the model in this paper once recourse is made to computer simulation. Thus, in work now underway with Michael Bruno, a three-sector infinitehorizon model of the U.K. is being developed, that incorporates a complete input-output structure in the production technology.

The second extension, to explicitly treat restrictions on capital mobility, would allow a more accurate depiction of the degree of capital mobility among the OECD economies. Most of the major economies have or continue to resort to restrictions on international capital flows to help achieve current account and other objectives. Foreign access to the U.S. bond market was effectively closed until 1974, and until much more recently in Japan. Our understanding of theoretical aspects of capital controls is still rather limited, and controls are rarely brought in explicitly into theoretical work.

The third direction is by far the hardest. To this point we have very little feel for the relevant sources of risk that lead to the imperfect substitutability of assets across national borders. Our models will have radically different conclusions if imperfect substitutability is based on 
inflation risk, default risk, political risk, or hedging behavior against still other types of real disturbances. It seems that the most fruitful way to proceed here is to build small theoretical models, with attention to a limited number of key stochastic elements, so that portfolio behavior may be derived endogenously. 
1/ Harberger, A.C., "Vignettes on the World. Capital Market," American Economic Review, May, 1980.

2/ For background on the extensive role of Japanese Capital Controls until the mid-1970's, see Seki, Kaname, "Foreign Exchange Law," the Japan Business Law Journa1, Vo1. 1 (Ju1y 1980).

3/ Halevi, N., "An Empirical Test of the Balance of Payments States" Hypothesis," Journal of International Economics, Vol 1 (February 1971).

4/ Until, of course, joining the European Monetary System in 1979.

5/ Finland began pegging, to a basket of currencies on Nov. 1, 1977. Norway was in the Snake until December 12, 1978, at which point it began pegging to a basket of currencies. Austria was in the Snake off and on throughout the $70^{\prime} \mathrm{s}$, alternating between the joint European float and a closer connection with the Deutchmark. Denmark was a member of the Snake, and now the EMS. Sweden has pegged to a basket of currencies since the mid-1970's. 
Dornbusch, Rudiger and Stanley Fischer, "Exchange Rates and the Current Account," American Economic Review, December, 1980.

Feldstein, Martin and Charles Harioka, "Domestic Savings and International Capital Flows," Economic Journal, 1981.

Halevi, N., "An Empirical. Test of the 'Balance of Payments Stages' Hypothesis," Journal of International Economics, Vol. 1 (February 1971).

Harberger, Arnold C., "Vignettes on the World Capital Market," Papers and Proceedings of the American Economic Association, Alnerican Economic Review, pp. 331-337.

Kouri, Pentti J. K., "Balance of Payments and the Foreign Exchange Market: A Dynamic Partial Equilibrium Model," NBER Working Paper No. 644, March, 1981.

$\therefore$, "The Effect of Risk on Interest Rates: A Synthesis of the Macroeconomic and Financial Views," NBER Working Paper No. 643, March, 1981.

and Jorge Braga de Macedo, "Perspectives on the Stagflation of the 1970s," Woodrow Wilson School of Public and International Affairs, Princeton, Discussion Paper No. 91, December, 1980.

Lipton, David and Jeffrey Sachs, "Accumulation and Growth in a Two-Country Model," NBER Working Paper No. 570.

Obstfeld, Maurice, "Imperfect Asset Substitutability and Monetary Policy under Fixed Exchange Rates," Journal of International Economics, May, 1980.

Rodriguez C., "The Role of Trade Flows in Exchange Rate Determination: A Rational Expectations Approach," Journal of Political Economy, Vol. 88, No. 6, December, 1980.

Sachs, Jeffrey, "The Current Account and Macroeconomic Adjustment in the 1970 s," forthcoming in Brookings Papers on Economic Activity, 1981.

, "Energy and Growth under Flexible Rates," forthcoming in The International Transmission of Economic Disturbances under Flexible Exchange Rates, ed. by J. Bhandari and B. Putnam, M.I.T. Press, 1982.

Stockman, Alan, "A Theory of Exchange Rate Determination," Journal of Political Economy, Vo1. 88, No. 4, August, 1980. 
TABLE 1

CURRENT ACCOUNTS AS A PROPORTION OE GNP, 1960-79

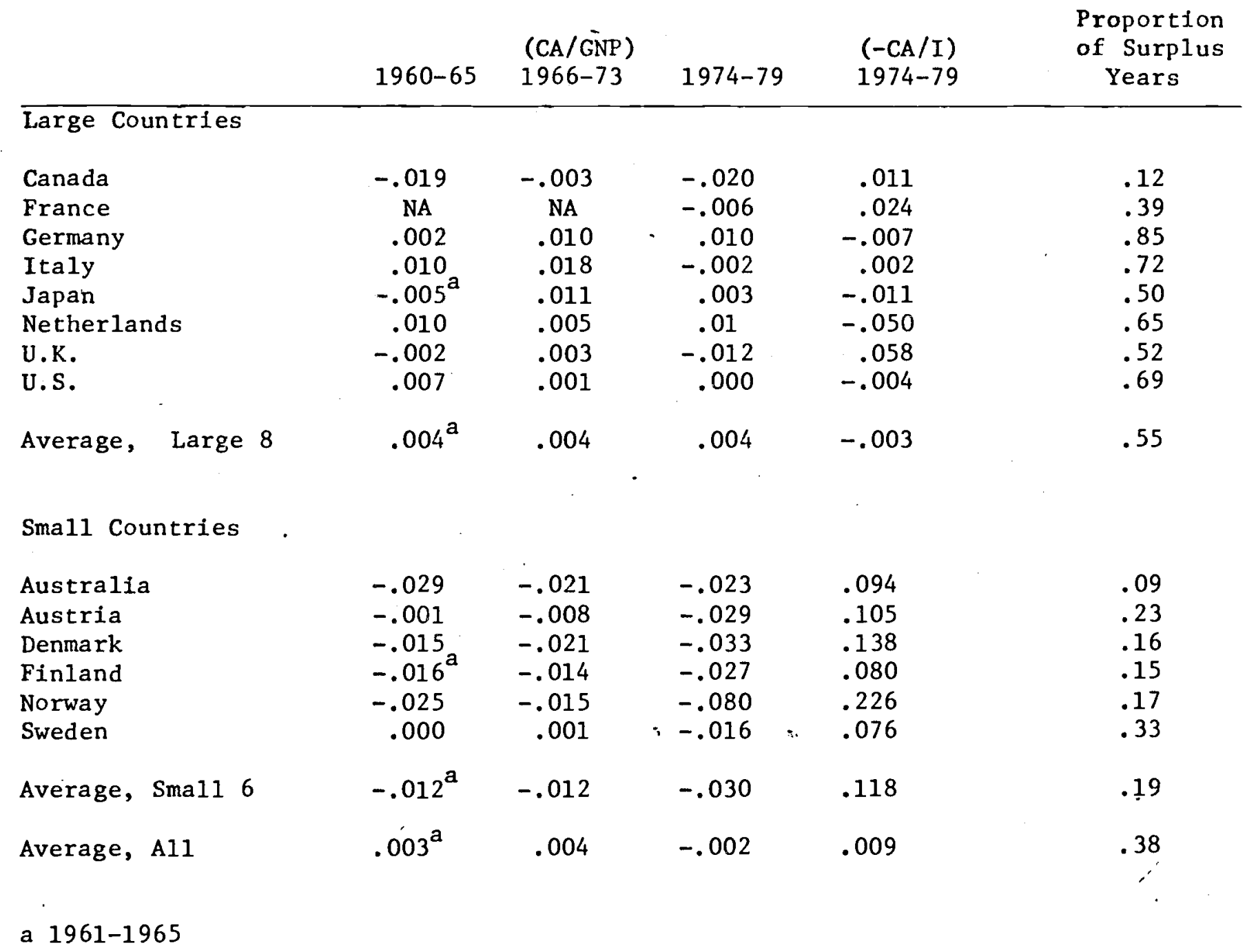

Source: Current account balance is from the OECD Main. Economic Indicators, Historical Statistics. GNP and I are from the International Financial Statistics, International Monetary Fund. 
TABLE 2

REGRESSION ANALYSIS OF CA/GNP

Country

1. Excluding Japan

$\begin{aligned} & \left(\frac{\mathrm{CA}}{\mathrm{GNP}}\right) \\ & 1961-70 \\ & (1.57)\end{aligned}-\underset{(1.82)}{.172}\left(\frac{\mathrm{I}}{\mathrm{GNP}}\right)$

.23

2. Excluding Japan

$\frac{\left(\frac{\mathrm{CA}}{\mathrm{GNP}}\right)}{1971-79 .}=\underset{(3.58)}{.084}-\underset{(4.10)}{.39}\left(\frac{\mathrm{I}}{\mathrm{GNP}}\right)$

.60

3. A11

$\begin{aligned} & \left.\frac{\mathrm{CA}}{\mathrm{GNP}}\right)_{1971-79}^{.039} \\ & (1.49)\end{aligned}-\underset{(1.89)}{.20}\left(\frac{\mathrm{I}}{\mathrm{GNP}}\right)$

4. A11

$\frac{\left(\frac{C A}{G N P}\right)}{1961-70}$

$$
=-.0004-\frac{-.002^{(\$ G N P / P o p u l a t i o n)}}{(.03)}(.47) \quad 1961-70
$$

$$
\begin{aligned}
& \left(\frac{\mathrm{CA}}{\mathrm{GNP}}\right) \\
& 1971-79
\end{aligned}
$$

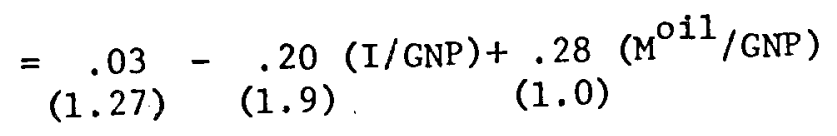

6. Excluding Japan

$$
\underset{\substack{\mathrm{GNP} \\ 1971-79}}{(-08}-\underset{(3.2)}{.08}-\underset{(4.0)}{.39}(\mathrm{I} / \mathrm{GNP})+\underset{(.43)}{.09\left(\mathrm{M}^{\mathrm{Oil}} / \mathrm{GNP}\right)}
$$

$\Delta\left(-\frac{\mathrm{CA}}{\mathrm{GNP}}\right)$

(1971-79)

$-(1961-70)$

8. Excluding France ${ }^{\mathrm{b}} \Delta\left(\frac{\mathrm{CA}}{\mathrm{GNP}}\right)$

(1971-79)

$-(1961-70)$

$$
=\begin{array}{cc}
-.01 & -.65 \Delta(I / G N P) \\
(4.2) & (4.6)
\end{array}
$$

.65

$$
\begin{aligned}
& =-.01-.15 \Delta(\mathrm{S} / \mathrm{GNP}) \\
& \text { (1.1) (.34) }
\end{aligned}
$$

a Numbers in parentheses are t-statistics

b Missing Observations for France prevented inclusion

Sources: CA from OECD Main Fconomic Indicators; GNP from international. Financial Statistics. I is total gross investment, including inventory accumulation, from IFS. Savings, $S$, are defined as I + CA. The notation ( ) $1961-70$ or ( ) 1971-79 indicates a simple arithmetic average over the years indicated. $\Delta()_{(1971-79)}$ indicates $\left[()_{71-79)}-()_{61-70}\right]$. The full country 1ist is as is $-(19.61-70)$ in Table 1. 
TABLE 3

THE CURRENT ACCOUNT AND EXCHANGE RATE MOVEMENTS

\begin{tabular}{|c|c|c|c|c|}
\hline & & End 1979 & Correlation $^{a}$ & Correlation $^{b}$ \\
\hline $\mathrm{CA} / \mathrm{GNP}$ ) & $\%(E)$ & $\%(E P * / P)$ & of $\mathrm{CA} / \mathrm{GNP}$, & of $\mathrm{CA} / \mathrm{C}$ \\
\hline
\end{tabular}

74-79

(annual rate) (annual rate)

$\%(E)$

$\%(\mathrm{EP} * / \mathrm{P})$

Large E1ght

$\begin{array}{lrrrrr}\text { Canada } & -.020 & 5.0 & 3.8 & .09 & -28 \\ \text { France } & -.006 & -1.2 & -0.2 & -.38 & -.59 \\ \text { Germany } & .010 & -7.5 & -2.1 & -.28 & -.31 \\ \text { Italy } & -.002 & 7.5 & -0.7 & -.58 & -.26 \\ \text { Japan } & .003 & -1.0 & 0.3 & -.10 & -.71 \\ \text { Netherlands } & .011 & -5.4 & -1.1 & -.14 & -.50 \\ \text { U.K. } & -.012 & 3.5 & -2.6 & -.40 & -.06 \\ \text { U.S. } & .000 & 3.0 & 2.6 & -.58\end{array}$

$\underline{\text { Small }} \underline{\text { Six }}$

Australia

Austria

Denmark

Finland

Norway

Sweden

$$
-.023
$$$$
-.029
$$$$
-.033
$$$$
-.027
$$$$
-.080
$$$$
-.016
$$

\begin{tabular}{|c|c|}
\hline 4.5 & 2.5 \\
\hline-6.6 & -1.6 \\
\hline-1.1 & -1.3 \\
\hline 0.7 & -1.4 \\
\hline-1.9 & -1.0 \\
\hline 0.5 & $\therefore \quad-1.1$ \\
\hline
\end{tabular}

$-.11$

.27

.04

.01

.04

$-.29$
$-.54$

.29

$-.05$

.49

$-.19$

.05
a Quarter1y, 1974:1 - 1979:4
b Annua1, $1973-1979$

Source: CA and GNP as in Table 1. The exchange rate for country $i$ is calculated as $\log \left(E_{i}\right)=\left[\sum_{j \neq i} w_{j} \log \left(E_{i j}\right)\right] /\left(1-w_{i}\right)$, where $w_{j}$ is the share of country $j$ in total exports plus imports, on average, during 1968-73. That is, $\left.w_{j}=\left(x_{j}+M_{j}\right) / \sum_{k}^{[}\left(x_{k}+M_{k}\right)\right]_{1968-73}$, with $x_{j}, M_{j}$ equal to the dollar values of total exports and imports for country $j \cdot E_{i j}$ is an index of the end-of-period bilateral exchange rate between countries $i, j$, in units of currency $i$ per unit of currency $j\left(E_{i j} \equiv 1\right.$ in 1975). The series $E_{1 j}$ is calculated from the International Financial Statistics, IMF, using the series Lae for each country. $E P * / P$ is anallogously calculated as

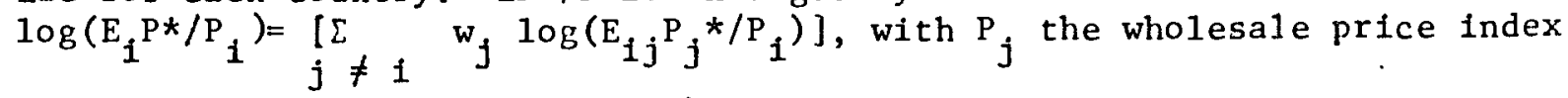
of country $j$ (also from IFS data). 
TABLE 4

REGRESSIONS OF \% $\triangle E$ ON $\frac{\text { CA }}{\text { GNP}}$, QUARTERLY 1974:1-1980:4

Country

Independent Variables

Large Elght

Canada

$74: 1-$

$.01 \quad .08$

Interval $\quad \mathrm{C} \quad \underline{\mathrm{CA}} \quad \underline{(\% \Delta \mathrm{E})-1} \stackrel{(\% \Delta \mathrm{E})-2}{(}$

$\underline{R^{2}}$

d.w.

$80: 4$

(.89) $(.14)$

Germany

$74: 1-$

$\begin{array}{cc}-.007 & -.72 \\ (1.1) & (1.2) \\ & \\ -.006 & -.81 \\ (.91) & (2.2)\end{array}$

$\begin{array}{ll}.01 & .16 \\ (.89) & (.27)\end{array}$

.16

$-.027$

.02

1.98

$0.00 \quad 1.69$

$-.007-.79$

$74: 1-$

(1.2) (1.9)

$79: 4$

$79: 4$

$-.012-.82$

$-.30$

$-.27$

.15

1.6

(1.7) (2.4)

(1.7)

(1.5)

.15

1.77

(.28)

.0005
$(.002)$

$.16 \quad 2.21$

$.29 \quad 1.68$

Italy

$74: 1$

$.016--.45$

(1.8) (1.5)

$.020-.64$

-.32
$(1.4)$

.07

$79: 4$

(2.0)

(2.0)

(.37)

$.19, \quad 1.9$

$\begin{array}{rr}-.008 & -1.13 \\ (.98) & (1.8)\end{array}$

$.11 \quad 1.12$

Japan

$74: 1-$

$80: 4$

$-.006-.12$

(.72) (.14)

$.28 \quad 1.92$

$.03 \quad 2.24$

$-.008-.19$

(1.6) (.85)

$-.014-.20$

$.19 \quad 1.78$

$80: 3$

(2.4) (.95)

$.04 \quad 1.46$

$-.012-.41$

(.15) (1.0)

$-.001-.34$

$.13 \quad 2.10$

$80: 3$

$(.22) \quad(.84)$

$.09 \quad 2.40$

United States 74:1 -

$.003-1.6$

(.49) (1.6)

$.005-2.3$

$(.76) \quad(2.3)$

$-.28$

(1.6)

$-.36$

(2.1)

.27

2.03 


\section{Country}

$\underline{\text { Sma11 Six }}$

Austra11a

Austria

Finland

Norway

Sweden

Denmark
TABLE 4 (cont'd)

Independent Variables

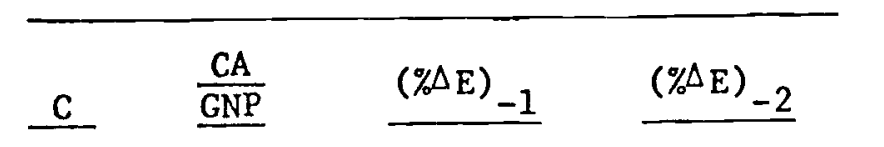

\begin{tabular}{|c|}
\hline $74: 1-$ \\
\hline
\end{tabular}

$80: 4$

$.005 \quad-.279$

$(.35) \quad(.48)$

$-.07$

$-.006$

(.03)

$.008 \quad 2.04$

$-.004 \quad .179$

$(0.54) \quad(.84)$

$\begin{array}{cc}-.012 & .180 \\ (1.31) & (.88)\end{array}$

$-.290$

$-.35$

$80: 4$

(1.5)

(1.8)

.02

2.08

$.013 \quad 1.91$

$74: 1=$

-.000
$(.02)$

.057

(.19)

$-.006$

$-.12$

(.32)

$-.03$

(.13)

$-.24$

.001

1.77

$79: 4$

(.48)

(.91)

$.04 \quad 1.78$

$74: 1-$

$79: 4$

$.003 \quad .008$

(.47) (.05)

$.001 \quad-.05$

(.09)

(.30)

.20

$.000 \quad 1.93$

$.039 \quad 2.04$

$-.0003 \quad .019$

$\begin{array}{ll}(.03) & (.17) \\ 0.0 & .02\end{array}$

$(0.0)$

(.19)

$-.22$

.09
$(.46)$

0.0 ,

1.82

$79: 4$

$\begin{array}{ll}-.01 & -.60 \\ (1.16) & (1.41) \\ -.02 & -.70\end{array}$

$-.02$

.33

$79: 4$

(1.36)

(1.61) (1.62)

$-.03$

(.147)

$.06 \quad 1.95$

$.08 \quad 1.30$

$.19 \quad 1.92$ 
TABLE 5

THE "ACCELERATIONIST" HYPOTHESIS:

CA AND EXCHANGE RATE CHANGES, ANNUAL

OBSERVATIONS, 1973-1980

Number of Years in Which:

Country

Large Eight

Canada

Nominal

Real

France

Nominal

Real

Germany

Nominal

Rea 1

Italy

Nomina 1

Real

Japan

Nominal

Real

Netherlands

Nomina1

Real

U.K.

Nominal

Real

U.S. NominaI

Real

Subtota1, Large 8 Nominal

Real

2
Surplus- Deficit-

Surplus

Appreciation Depreciation Depreciation
Percent of

Observatiors

in

Deficit

Appreciation
Support of

Hypothesis
37.5

50

50

87.5

75

87.5

67

57

62.5

67

57

71

62.5

50

75

50

3

1

60.5

16

77.5 
Sma 11 Six

Australia

Nominal

Real

$\begin{array}{ll}1 & 5 \\ 1 & 4\end{array}$

75

67.5

Austrla

Nominal

Real

$\begin{array}{ll}0 & 2 \\ 0 & 4\end{array}$

6

25

50

Denmark

Nominal

Real

0
0

4
4

50

50

Finland

Nominal

Rea 1

0

0

2

1 .

25

12.5

Norway

Nomina 1

Real

0 .

1

1

37.5

4

62.5

Sweden

Nominal

Real

$\begin{array}{ll}0 & 3 \\ 0 & 3\end{array}$

37.5

37.5

Subtotal, Sma11 6 Nominal

Real

41.5

Tota1, (15) Countries Nomina 1

Rea 1
20

22
37

41
11

9
41

38
52.0

57.0

$$
\begin{aligned}
& x_{1}^{2}=3.3^{\mathrm{a}} \text { Large Eight, Nominal } \\
& \chi_{1}^{2}=7.1 \quad \text { Large Eight, Real } \\
& x_{1}^{2}=1: 5 \text { Small Six, Nominal } \\
& \chi_{1}^{2}=0.0 \text { Small Six, Real } \\
& x_{1}^{2}=1.3 \text { Total, Nominal } \\
& x_{1}^{2}=4.7 \text { Total, Rea } 1
\end{aligned}
$$

$$
\begin{aligned}
& p<.10 \\
& p<.01 \\
& p>.10 \\
& p>.10 \\
& p>.10 \\
& p<.05
\end{aligned}
$$

a Pearson statistic 


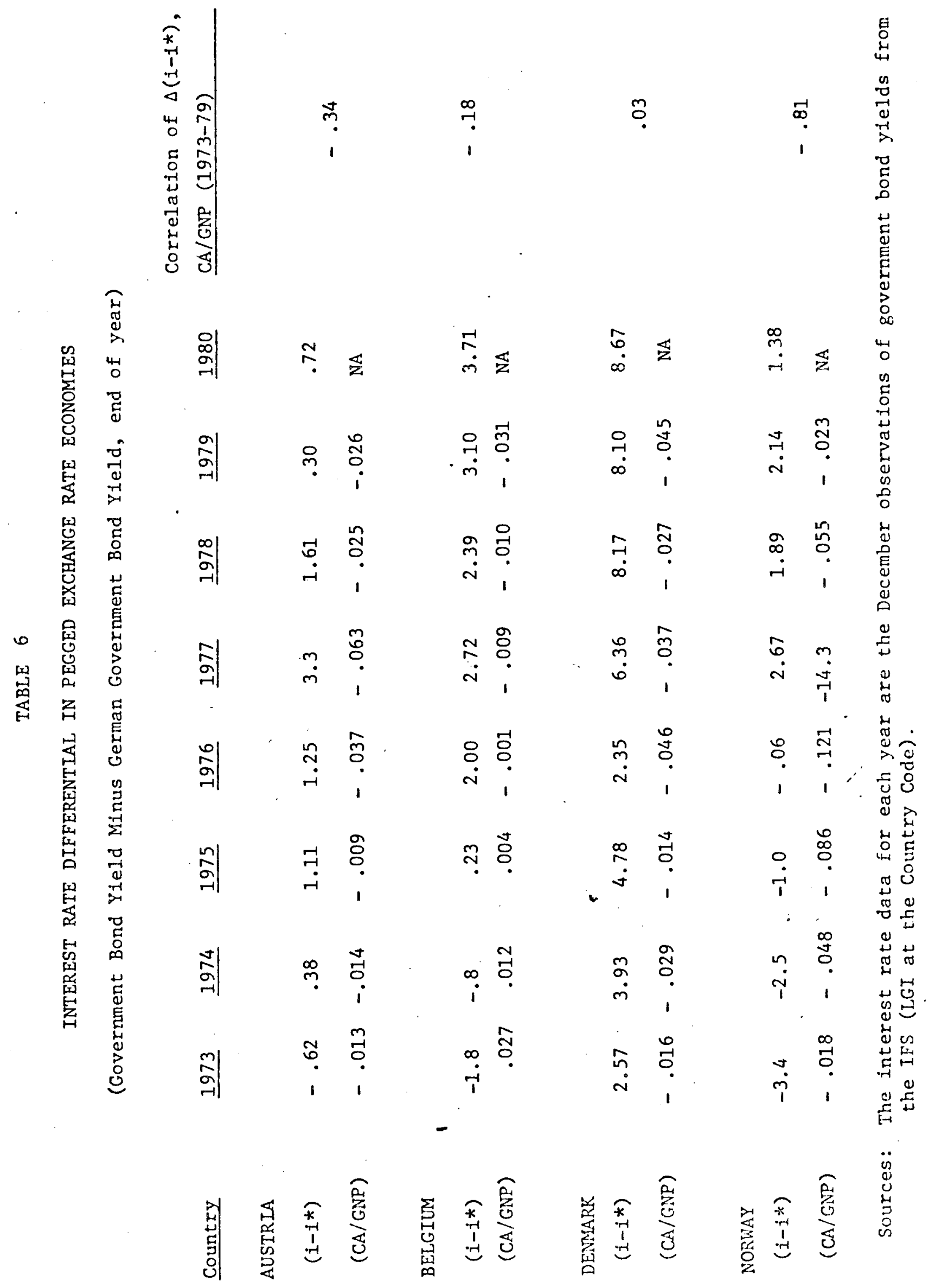

